Supplement of Geogr. Helv., 70, 265-279, 2015

http://www.geogr-helv.net/70/265/2015/

doi:10.5194/gh-70-265-2015-supplement

(C) Author(s) 2015. CC Attribution 3.0 License.

(c) (i)

+ GEOGRAPHICA

HELVETICA +

Supplement of

\title{
Methods for detecting channel bed surface changes in a mountain torrent - experiences from the Dorfbach torrent
}

C. Willi et al.

Correspondence to: M. Keiler (margreth.keiler@giub.unibe.ch)

The copyright of individual parts of the supplement might differ from the CC-BY 3.0 licence. 
S 1 Guideline for choosing the appropriated method according to the aims of application and analysis

\begin{tabular}{|c|c|c|c|c|c|c|c|}
\hline \multirow{3}{*}{\multicolumn{2}{|c|}{$\begin{array}{l}\text { Research question: } \\
\text { Methods to localise and quantify erosion and } \\
\text { deposition in torrent channels }\end{array}$}} & \multirow[t]{3}{*}{ Requirements } & \multirow{3}{*}{$\begin{array}{l}\text { In-situ methods } \\
\text { Erosion sensors } \\
\text { Berger et al. (2010; 2011a); } \\
\text { McArdell (2012, personale commu- } \\
\text { nication) } \\
\text { Fritschi (2012, personale communi- } \\
\text { cation) }\end{array}$} & \multirow{3}{*}{$\begin{array}{l}\text { Cross sections } \\
\text { TruPulse and dGPS } \\
\text { Own application }\end{array}$} & \multirow{3}{*}{$\begin{array}{l}\text { Terrain models } \\
\text { Terrestrial Laser Scanning } \\
\text { Own application }\end{array}$} & \multirow{3}{*}{$\begin{array}{l}\text { LiDAR } \\
\text { Scheidl et al. (2008); } \\
\text { Scheidl (2012, personale com- } \\
\text { munication) }\end{array}$} & \multirow{3}{*}{$\begin{array}{l}\text { Qualitative methods } \\
\text { Geomorphological mapping } \\
\text { Own application }\end{array}$} \\
\hline & & & & & & & \\
\hline & & & & & & & \\
\hline \multirow[t]{4}{*}{$\begin{array}{l}\text { Location and } \\
\text { process }\end{array}$} & $\begin{array}{l}\text { Process and process char- } \\
\text { acteristics }\end{array}$ & $\begin{array}{l}\text { Channel changes caused by } \\
\text { debris-flows: dimension and } \\
\text { position of extensive struc- } \\
\text { tures should be measureable }\end{array}$ & $\begin{array}{l}\text { Time, duration and extent (max. } \\
\Delta \mathbf{z} \text { ) of erosion caused by debris- } \\
\text { flows. Detection of deposition is not } \\
\text { provided. }\end{array}$ & $\begin{array}{l}\text { Extent (net } \Delta \mathbf{z} \text { and } \Delta \mathbf{F} \text { ) of } \\
\text { erosion and deposition caused } \\
\text { by debris-flows in a certain } \\
\text { cross section. }\end{array}$ & $\begin{array}{l}\text { Extent (net } \Delta \mathbf{z} \text { and } \Delta \mathbf{V} \text { ) of erosion } \\
\text { and deposition caused by debris- } \\
\text { flows for a confined torrent area. } \\
\text { Pattern are detectable. }\end{array}$ & $\begin{array}{l}\text { Extent (net } \Delta \mathbf{z} \text { and } \Delta \mathbf{V} \text { ) of ero- } \\
\text { sion and deposition caused by } \\
\text { debris-flows for a confined tor- } \\
\text { rent area. Pattern are detectable. }\end{array}$ & $\begin{array}{l}\text { Tendencies of changes }(\Delta \mathbf{z}) \text { area- } \\
\text { wide for the whole torrent channel. } \\
\text { Pattern are detectable, no quantita- } \\
\text { tive (only estimated) results. }\end{array}$ \\
\hline & $\begin{array}{l}\text { Channel properties and } \\
\text { conditions }\end{array}$ & $\begin{array}{l}\text { 8-3 m wide channel with a } \\
\text { channel bed consisting of } \\
\text { coarse debris and levees up to } \\
4 \mathrm{~m} \text { high }\end{array}$ & $\begin{array}{l}\text { Application only in torrent channels } \\
\text { with fine grained bed (d } 90<0.3-0.5 \\
\text { m) possible. }\end{array}$ & $\begin{array}{l}\text { Application difficult with steep } \\
\text { or instable bank and missing } \\
\text { slopes, measurement sites pref- } \\
\text { erable outside the channel. }\end{array}$ & $\begin{array}{l}\text { Application difficult if banks are } \\
\text { steep or unstable. High banks and } \\
\text { narrow channels are also inappropri- } \\
\text { ate. Measurement sites preferable } \\
\text { outside the channel. }\end{array}$ & $\begin{array}{l}\text { Application is hindered if the } \\
\text { channel is strongly vegetated or } \\
\text { hardly visible or if banks are } \\
\text { steep. Inaccuracies and errors } \\
\text { increase. }\end{array}$ & $\begin{array}{l}\text { Application independent of the } \\
\text { channel properties possible. }\end{array}$ \\
\hline & $\begin{array}{l}\text { Access to the torrent } \\
\text { channel }\end{array}$ & $\begin{array}{l}\text { The torrent channel is acces- } \\
\text { sible on hiking trails. The } \\
\text { channel itself is walkable } \\
\text { with mountaineering boots. }\end{array}$ & $\begin{array}{l}\text { Punctual access to the channel by a } \\
\text { roadway, accessibility of the channel } \\
\text { necessary. }\end{array}$ & $\begin{array}{l}\text { Access to the channel by walk- } \\
\text { able banks is sufficient, acces- } \\
\text { sibility of banks and channel } \\
\text { necessary. }\end{array}$ & $\begin{array}{l}\text { Access to the channel by a roadway } \\
\text { or path, good accessibility of the } \\
\text { channel necessary. }\end{array}$ & $\begin{array}{l}\text { No access to the torrent channel } \\
\text { necessary. }\end{array}$ & $\begin{array}{l}\text { Access to the channel by walkable } \\
\text { banks is sufficient, accessibility of } \\
\text { banks and channel necessary. }\end{array}$ \\
\hline & $\begin{array}{l}\text { Application during/ after } \\
\text { massive channel changes }\end{array}$ & $\begin{array}{l}\text { Channel changes up to } 10 \mathrm{~m} \\
\text { difference are realistic. }\end{array}$ & $\begin{array}{l}\text { Sensors no more applicable after a } \\
\text { major event; sensors would erode } \\
\text { completely or would be massively } \\
\text { covered - no data. }\end{array}$ & $\begin{array}{l}\text { Method not applicable anymore } \\
\text { due to reduced view, eroded/ } \\
\text { covered marks, unstable banks, } \\
\text { missing accessibility to the } \\
\text { channel. }\end{array}$ & $\begin{array}{l}\text { Method may not be applicable any- } \\
\text { more due to reduced view, missing } \\
\text { GPS signal for georeferencing, miss- } \\
\text { ing accessibility to the channel. }\end{array}$ & $\begin{array}{l}\text { Method applicable, reduced view } \\
\text { and data accuracy with steepened } \\
\text { channel and banks. }\end{array}$ & $\begin{array}{l}\text { Method applicable, as long as the } \\
\text { channel is accessible or at least } \\
\text { visible, varieties in the amount of } \\
\text { changes hardly differentiable. }\end{array}$ \\
\hline \multirow[t]{6}{*}{ Quality criteria } & $\begin{array}{l}\text { Scope of application (in- } \\
\text { vestigation during only one } \\
\text { day) }\end{array}$ & $\begin{array}{l}\text { Continuous, extensive detec- } \\
\text { tion of the analysed channel } \\
\text { section or entire channel as } \\
\text { far as possible. }\end{array}$ & $\begin{array}{l}\text { Point-based detection in a small } \\
\text { space inside the analysed channel } \\
\text { section. }\end{array}$ & $\begin{array}{l}\text { Point-based cross sectional } \\
\text { detection spread over the entire } \\
\text { channel (interpolation between } \\
\text { single cross sections feasible). }\end{array}$ & $\begin{array}{l}\text { Confined area(s) of the analysed } \\
\text { channel section. }\end{array}$ & $\begin{array}{l}\text { Total area of the analysed chan- } \\
\text { nel section. }\end{array}$ & $\begin{array}{l}\text { Total area of the analysed channel } \\
\text { section. }\end{array}$ \\
\hline & Accuracy of the raw data & $\begin{array}{l}10^{-2} \mathrm{~m} \text {-range up to m-range, } \\
\text { depending on the intended } \\
\text { use of the data. }\end{array}$ & $\begin{array}{l}0.05 \mathrm{~m} \text { resolution in correspondence } \\
\text { to a single sensor element }\end{array}$ & $\begin{array}{l}\text { dGPS: horizontal and vertical } \\
\text { precision +/- } 0.1 \mathrm{~m} \\
\text { TruPulse: Distance }+/-0.3 \mathrm{~m} \\
\text { Inclination: }+/-0.25^{\circ} \\
\text { Azimuth: }+/-1^{\circ} \text { (LTI, 2009:52; } \\
\text { Trimble, 2011) }\end{array}$ & $\begin{array}{l}\text { Modelled surface: } 0.002 \mathrm{~m} \\
\text { (Leica 2012) }\end{array}$ & $\begin{array}{l}\text { Location: }+/-0.1 \mathrm{~m} \\
\text { Height: }+/-0.5 \mathrm{~m} \\
\text { (Standard accuracy according to } \\
\text { Vosselman and Maas, 2010:21) }\end{array}$ & $\begin{array}{l}\text { Location: multiple meters } \\
\text { Height: not observable } \\
\text { Mapping accuracy varies depend- } \\
\text { ing on the mapping base and scope } \\
\text { for interpretation. }\end{array}$ \\
\hline & Accuracy of the final data & $\begin{array}{l}10^{-1} \mathrm{~m} \text {-range up to m-range, } \\
\text { depending on the intended } \\
\text { use of the data. }\end{array}$ & $\begin{array}{l}0.05 \mathrm{~m} \text { resolution in correspondence } \\
\text { to a single sensor element and inac- } \\
\text { curacies in } 10^{-1} \mathrm{~m} \text {-range due to depo- } \\
\text { sition on the sensor and measurement } \\
\text { device. }\end{array}$ & $\begin{array}{l}\text { Location: in the range of } 0.5 \mathrm{~m} \\
\text { Height: in the range of } 0.5 \mathrm{~m}\end{array}$ & $\begin{array}{l}\text { Location: }<0.3 \mathrm{~m} \\
\text { Height: in the range of } 0.3 \mathrm{~m}\end{array}$ & $\begin{array}{l}\text { Location: } 0.3-0.5 \mathrm{~m} \\
\text { Height: } 0.1-0.3 \mathrm{~m} \\
\text { (data for CH mountain torrents, } \\
\text { also realistic in the Dorfbach } \\
\text { torrent). }\end{array}$ & $\begin{array}{l}\text { Location: multiple meters (strongly } \\
\text { influenced by the interpretation of } \\
\text { mapping person). } \\
\text { Height: Changes only detectable as } \\
\text { tendencies. }\end{array}$ \\
\hline & Spatial resolution & $\begin{array}{l}2-3 \mathrm{~m} \text { or }<0.5 \mathrm{~m} \text {, depending } \\
\text { on the intended use of the } \\
\text { data }\end{array}$ & $\begin{array}{l}5 \text { measurements on } 20 \mathrm{~m}^{2} \text {, remaining } \\
\text { channel not covered }\end{array}$ & $\begin{array}{l}\text { Cross sectional resolution in } 10^{-} \\
{ }^{2} \mathrm{~m} \text {-range } \\
\text { Distance between cross sec- } \\
\text { tions: } 50-150 \mathrm{~m}\end{array}$ & Enables $10^{-1} \mathrm{~m}$-raster & $\begin{array}{l}\text { Raster resolution 0.5-5 m (Ogu- } \\
\text { chi et al. 2011) }\end{array}$ & $\begin{array}{l}\text { In the range of } 5-30 \mathrm{~m} \text {, depending } \\
\text { on the mapping base and scope for } \\
\text { interpretation. }\end{array}$ \\
\hline & Temporal resolution & $\begin{array}{l}\text { Measurements during or after } \\
\text { each event or at least once a } \\
\text { month (to elimininate continu- } \\
\text { ous changes). }\end{array}$ & $\begin{array}{l}\text { Permanently installed and ready } \\
\text { for measurements, time limits of } \\
\text { erosion during an event are exactly } \\
\text { detectable. }\end{array}$ & $\begin{array}{l}\text { Data collection few days up to } \\
\text { max. one month before and } \\
\text { after an event, at any time } \\
\text { possible if the channel is acces- } \\
\text { sible. }\end{array}$ & $\begin{array}{l}\text { Data collection few days up to } \\
\text { max. one month before and after } \\
\text { an event, at any time possible if the } \\
\text { channel is accessible. }\end{array}$ & $\begin{array}{l}\text { Data collection few weeks up to } \\
\text { several months before and } \\
\text { after an event, lack of temporal } \\
\text { resolution due to financial rea- } \\
\text { sons. }\end{array}$ & $\begin{array}{l}\text { Data collection few days up to } \\
\text { max. one month before and after } \\
\text { an event, at any time possible if } \\
\text { the channel is accessible. }\end{array}$ \\
\hline & Repeatability & Necessary & $\begin{array}{l}\text { Possible, due to permanent installa- } \\
\text { tion. }\end{array}$ & $\begin{array}{l}\text { Possible, as long as measure- } \\
\text { ments sites are outside the tor- } \\
\text { rent channel. }\end{array}$ & $\begin{array}{l}\text { Possible, fixed targets or georefer- } \\
\text { encing necessary. }\end{array}$ & Possible & $\begin{array}{l}\text { Possible, it should be noted that } \\
\text { every mapping leaves scope for } \\
\text { interpretation. }\end{array}$ \\
\hline
\end{tabular}




\begin{tabular}{|c|c|c|c|c|c|c|c|}
\hline \multirow[t]{8}{*}{$\begin{array}{l}\text { Organisational } \\
\text { aspects }\end{array}$} & $\begin{array}{l}\text { Suitability of the material } \\
\text { for field investigations }\end{array}$ & $\begin{array}{l}\text { Material must be portable in } \\
\text { difficult terrain. }\end{array}$ & $\begin{array}{l}\text { Single use of an excavator necessary; } \\
\text { durability of the sensors lowered in a } \\
\text { humid channel bed. }\end{array}$ & $\begin{array}{l}\text { Measurement devices and tri- } \\
\text { pod are handy and transportable } \\
\text { by one person. }\end{array}$ & $\begin{array}{l}\text { Measurement device is heavy, multi- } \\
\text { pieced and only transportable by } \\
\text { multiple people. }\end{array}$ & - & $\begin{array}{l}\text { Necessary material transportable } \\
\text { without problems. }\end{array}$ \\
\hline & $\begin{array}{l}\text { Total expenditure (for } \\
\text { preparation, data collection, } \\
\text { processing and analysis to } \\
\text { gain data from one event) }\end{array}$ & - & $\begin{array}{l}\text { Approx. } 13 \text { person-days, however } \\
\text { decreasing with every further event } \\
\text { ( } 1 \text { week for development and man- } \\
\text { ufacturing). }\end{array}$ & $\begin{array}{l}\text { Approx. 8-9 person-days } \\
\text { caused by time-consuming data } \\
\text { correction. }\end{array}$ & $\begin{array}{l}\text { Approx. 14-15 person-days mainly } \\
\text { due to diverse work steps and data } \\
\text { correction. }\end{array}$ & $\begin{array}{l}\text { 9-10 person-days if data collec- } \\
\text { tion and preparation is carried } \\
\text { out by a professional company } \\
\text { (Helimap 2011). }\end{array}$ & $\begin{array}{l}\text { Approx. 2-3 work-days, expendi- } \\
\text { ture depending on level of detail. }\end{array}$ \\
\hline & $\begin{array}{l}\text { Expenditure for field work } \\
\text { (for the collection of the } \\
\text { data of one event) }\end{array}$ & $\begin{array}{l}\text { Maximum one day of field } \\
\text { investigation for each meas- } \\
\text { uring period. }\end{array}$ & $\begin{array}{l}\mathbf{6} \text { person-days for installation (addi- } \\
\text { tional field work for detecting the } \\
\text { height of sediment cover over the } \\
\text { erosion sensors) }\end{array}$ & $\begin{array}{l}2 \text { x } 2 \text { person-days for } 6-7 \text { cross } \\
\text { sections spread over } 260 \mathrm{~m} \\
\text { altitude }\end{array}$ & $\begin{array}{l}2 \times 3 \text { person-days for } 2 \text { areas of } 70 \\
\mathrm{~m} \times 20 \mathrm{~m} \text { with } 5 \text { scans each }\end{array}$ & $\begin{array}{l}\text { No field work necessary (only } \\
\text { for plausibility check) } \\
\text { (data collection } 2 \text { x } 2 \text { person- } \\
\text { days (Helimap 2011)) }\end{array}$ & $\begin{array}{l}2 \mathrm{x}<\mathbf{1 / 2} \text { person-day for detailed } \\
\text { mapping of studied channel reach }\end{array}$ \\
\hline & $\begin{array}{l}\text { Post-processing expendi- } \\
\text { ture (for the processing of } \\
\text { the data of one event) }\end{array}$ & - & $<30$ minutes & $\begin{array}{l}\text { Approx. 3-4 days depending } \\
\text { on the data quality. }\end{array}$ & $\begin{array}{l}\text { Approx. 5-7 days, mainly due to } \\
\text { manual data correction. }\end{array}$ & $\begin{array}{l}2 \text { days work by a professional } \\
\text { company for a } 250 \text { ha area } \\
\text { (Helimap 2011) }\end{array}$ & $\begin{array}{l}\text { Approx. } 1 \text { day, mainly for digitiz- } \\
\text { ing and dGPS data preparation. }\end{array}$ \\
\hline & $\begin{array}{l}\text { Assistant needs for the } \\
\text { field investigation }\end{array}$ & - & $\begin{array}{l}2 \text { people, including an excavator } \\
\text { driver }\end{array}$ & 1 person & Minimum 2 people & - & No need, except for safety reasons. \\
\hline & Further aspects & - & $\begin{array}{l}\text { Distinctive intervention in the chan- } \\
\text { nel bed necessary to install the sen- } \\
\text { sors. }\end{array}$ & $\begin{array}{l}\text { Accuracy of georeferencing } \\
\text { depends on the satellite availa- } \\
\text { bility. }\end{array}$ & $\begin{array}{l}\text { Lower resolution and quality re- } \\
\text { quirements massively lower work } \\
\text { expenditure. }\end{array}$ & $\begin{array}{l}\text { LiDAR data collection expensive } \\
\text { in comparison to other methods. }\end{array}$ & $\begin{array}{l}\text { Mapping base: 1:5'000 to 1:25'000 } \\
\text { maps. }\end{array}$ \\
\hline & & & $\begin{array}{l}\text { Described sensor conforms to a top- } \\
\text { end version and could be produced } \\
\text { simpler and cheaper: as an alternative } \\
\text { to the aluminium case a PVC case } \\
\text { could be used. }\end{array}$ & $\begin{array}{l}\text { Atmospheric conditions influ- } \\
\text { ence the measurements. }\end{array}$ & $\begin{array}{l}\text { Atmospheric conditions influence } \\
\text { the measurements. }\end{array}$ & $\begin{array}{l}\text { Data collection only if weather } \\
\text { conditions are good, atmospher- } \\
\text { ic conditions influence the } \\
\text { measurements. }\end{array}$ & \\
\hline & & & $\begin{array}{l}\text { Excavator necessary, increases } \\
\text { costs. }\end{array}$ & & & $\begin{array}{l}\text { Helicopter needed for data col- } \\
\text { lection. }\end{array}$ & \\
\hline
\end{tabular}

